\title{
Syk interacts with tyrosine-phosphorylated proteins in human platelets activated by collagen and cross-linking of the $\mathrm{Fc} \gamma$-IIA receptor
}

\author{
Fumi YANAGA, ${ }^{*}$ Alastair POOLE, ${ }^{\star}$ Judith ASSELIN, ${ }^{\star}$ Robert BLAKE, ${ }^{\star}$ Gary L. SCHIEVEN, $\dagger$ Edward A. CLARK, $\ddagger$ Che-Leung LAW $\ddagger$ \\ and Steve P. WATSON\$* \\ *Department of Pharmacology, University of Oxford, Mansfield Road, Oxford OX1 3QT, U.K., †Department of Autoimmunity and Transplantation, Bristol Myers Squibb \\ Pharmaceutical Research Institute, Seattle, WA 98121, U.S.A., and ‡Department of Microbiology, SC-42, University of Washington, Seattle, WA 98195, U.S.A.
}

\begin{abstract}
Activation of human platelets by cross-linking of the platelet low-affinity IgG receptor, the Fc $\gamma$ receptor IIA (Fc $\gamma$-RIIA), or by collagen is associated with rapid phosphorylation on tyrosine of the non-receptor tyrosine kinase syk. Phosphorylation is still observed, albeit sometimes reduced, in the presence of a combination of a protein kinase $C$ inhibitor, Ro 31-8220, and the intracellular calcium chelator, BAPTA-AM, demonstrating independence from phosphoinositide-specific phospholipase C (PLC) activity. In contrast, the combination of Ro 31-8220 and BAPTA-AM completely inhibits phosphorylation of syk in thrombin-stimulated platelets. Phosphorylation of syk increases its autophosphorylation activity measured in a kinase assay performed on syk immunoprecipitates. Fc $\gamma$-RIIA also undergoes phosphorylation in syk immunoprecipitates from platelets activated by cross-linking of Fc $\gamma$-RIIA but not by collagen, suggesting that it associates with the kinase. Consistent with this, tyrosine-phosphorylated Fc $\gamma$-RIIA is precipitated by a glutathione S-transferase (GST) fusion protein containing the tandem src homology (SH2) domains of syk from Fc $\gamma$-RIIA-but not collagen-activated cells. Two uncharacterized tyrosinephosphorylated proteins of 40 and $65 \mathrm{kDa}$ are uniquely precipi-
\end{abstract}

tated by a GST fusion protein containing the tandem syk-SH2 domains in collagen-stimulated platelets. A peptide based on the antigen recognition activation motif (ARAM) of Fc $\gamma$-RIIA, and phosphorylated on the two tyrosine residues found within this region, selectively binds syk from lysates of resting platelets; this interaction is not seen with a non-phosphorylated peptide. Kinase assays on Fc $\gamma$-RIIA immunoprecipitates reveal the constitutive association of an unidentified kinase activity in resting cells which phosphorylates a $67 \mathrm{kDa}$ protein. Syk is not detected in Fc $\gamma$-RIIA immunoprecipitates from resting cells but associates with the receptor following activation and, together with $\mathrm{Fc} \gamma$ RIIA, is phosphorylated in the kinase assay in vitro. These results demonstrate that syk is activated by Fc $\gamma$-RIIA cross-linking and collagen, independent of PLC, suggesting that it may have an important role in the early events associated with platelet activation. The association of syk with Fc $\gamma$-RIIA appears to be mediated through the tandem SH2 domains in syk and the ARAM motif of Fc $\gamma$-RIIA. A similar interaction may underlie the response to collagen, suggesting that its signalling receptor contains an ARAM motif.

\section{INTRODUCTION}

Stimulation of platelets is associated with tyrosine phosphorylation of multiple proteins [1-3], and there is emerging evidence that this plays an important role in platelet activation. For example, we and others have reported that collagen and crosslinking of the platelet receptor for immune complexes, the lowaffinity IgG receptor, Fc $\gamma$-RIIA (CD32) [4], activate platelets through a tyrosine kinase-dependent pathway which involves tyrosine phosphorylation of phosphoinositide-specific phospholipase $\mathrm{C} \gamma 2$ (PLC $\gamma 2$ ) [5-8]. In contrast, PLC $\gamma 2$ does not undergo significant tyrosine phosphorylation in platelets activated by Gprotein receptor stimuli, e.g. thrombin and thromboxanes [6,7]. The identity of the tyrosine kinase which phosphorylates PLC $\gamma 2$ in collagen-and Fc $\gamma$-RIIA-stimulated platelets, and its mechanism of regulation, are not known.

There is evidence for a role of the tyrosine kinase syk in the signalling events associated with activation of Fc $\gamma$-RIIA in THP1 monocytic cells $[9,10]$, HL-60 monocytic cells [11] and human platelets [4]. Syk has two src homology 2 (SH2) domains [12] and belongs to the same family of tyrosine kinases as the $\mathrm{T}$-cell specific zap-70. Both kinases interact with a motif first identified by Reth [13] and known as the antigen receptor activation motif (ARAM; also called TAM and ARH1) (for review see [14,15]). The ARAM sequence, YXXL/I- $\mathrm{X}_{6-8}-\mathrm{YXXL} / \mathrm{I}$, where $\mathrm{X}$ is any residue, is found in the cytoplasmic domain of immune receptors, including the $\mathrm{T}$-cell antigen receptor, the B-cell antigen receptor, the high affinity IgE receptor (FceRI) and the $\mathrm{Fc} \gamma$ receptors (Fc $\gamma$-RI, Fc $\gamma$-RII and Fc $\gamma$-RIII) [14,16]. Fc $\gamma$-RIIA is unique in that this sequence is found on the cytosolic portion of the receptor rather than in an associated protein and in having twelve amino acids between repeating YXXL regions. Phosphorylation of the two tyrosines in the ARAM sequence is believed to take place on receptor clustering and enables the motif to be recognized by the tandem SH2 domains of syk and zap-70 [17,18].

It has recently been reported that syk is phosphorylated on tyrosine during platelet activation by a wide variety of stimuli, including G-protein receptor agonists, e.g. thrombin and thromboxanes [19,20], $\mathrm{Ca}^{2+}$ ionophore $\mathrm{A} 23187$ [21], activation of the fibrinogen receptor (integrin $\alpha_{110} \beta_{3}$ ) [22] and by agonists which induce receptor clustering, e.g. wheat germ agglutinin (WGA), collagen and immune complexes $[4,23,24]$. The mechanism through which these stimuli induce phosphorylation of

Abbreviations used: ARAM, antigen recognition activation motif; $\left[\mathrm{Ca}^{2+}\right]_{j}$, intracellular concentration of $\mathrm{Ca}^{2+} ; \mathrm{Fc} \gamma-\| \mathrm{A}$, platelet low-affinity lgG receptor, Fc $\gamma$ receptor IIA; GP, glycoprotein; GST, glutathione S-transferase; HRP, horseradish peroxidase; mAb, monoclonal antibody; PLC, phosphoinositide-specific phospholipase C; PVDF, poly(vinylidene difluoride); SH2 domain, src homology 2 domain; WGA, wheat germ agglutinin

$\S$ To whom correspondence should be addressed. 
syk is not known. In the present report we demonstrate that phosphorylation of syk on tyrosine is one of the earliest events that takes places on activation of platelets by Fc $\gamma$-RIIA and collagen and that this is independent of protein kinase $\mathrm{C}$ and elevation of intracellular $\mathrm{Ca}^{2+}\left(\left[\mathrm{Ca}^{2+}\right]_{1}\right)$. Evidence is presented to show that syk interacts with Fc $\gamma$-RIIA through its ARAM motif and it is speculated that a similar interaction may be involved in the activation of platelets by collagen. Syk is regulated in platelets by multiple pathways and may have a major role in mediating activation by collagen and immune complexes upstream of PLC $\gamma 2$.

\section{MATERIALS AND METHODS \\ Materials}

The anti-phosphotyrosine monoclonal antibody (mAb), 4G10, was purchased from Upstate Biotechnology Inc. (TCS Biologicals Ltd., Bucks., U.K.). The mAb IV.3, specific for Fc $\gamma$-RII, was purchased from Madarex Inc. (N.J., U.S.A.); a second antibody, raised against a conserved extracellular sequence found in $\mathrm{Fc} \gamma$ receptors, was used to detect Fc $\gamma$-RIIA in a Western-blotting experiment and was donated by Dr. K. Micklem (Nuffield Department of Pathology, John Radcliffe Hospital, Oxford, U.K.). An anti-syk rabbit polyclonal antibody raised against a polyhistidine fusion protein containing amino acids 257-352 within the linker region of syk was purchased from Santa Cruz, CA, U.S.A.; a second rabbit polyclonal antibody to syk was raised against a peptide sequence within the tyrosine kinase domain (CRADENYYKAQTHG) [25]. Rabbit antiserum raised against residues $461-481$ and $1218-1239$ of PLC $\gamma 2$ was prepared as described [26]. BAPTA-AM was purchased from CalbiochemNovabiochem (Nottingham, U.K.). Poly(vinylidene difluoride) (PVDF) Western-blotting membrane was from BioRad (Herts., U.K.). Collagen was from Nycomed (Munich, Germany). Ro 318220 was donated by Roche Products (Welwyn Garden City, Herts., U.K.). Tween-20, glutathione-agarose, protein ASepharose CL 4B, PMSF, staurosporine, thrombin and sheep $\mathrm{F}\left(\mathrm{ab}^{\prime}\right) 2$ raised against mouse $\mathrm{IgG}(\mathrm{M}-1522)$ were purchased from Sigma (Poole, Dorset, U.K.). ST271 and prostacyclin were gifts from the Wellcome Foundation (Beckenham, U.K.). Nonidet P40 (NP-40) was purchased from BDH (Poole, Dorset, U.K.). Horseradish peroxidase (HRP)-conjugated sheep anti-(mouse Ig) (NA931), HRP-conjugated donkey anti-(rabbit Ig) (NA934), enhanced chemiluminescence (ECL) reagents, Hyperfilm, protein biotinylation module and $\left[\gamma-{ }^{32} \mathrm{P}\right] \mathrm{ATP}$ were from Amersham International (Cardiff, U.K.). Tyrosine-phosphorylated [CDGGY(P)MTLNPRAPTDDDKNIY(P)LTLPPN] and nonphosphorylated (CDGGFMTLNPRAPTDDDKNIFLTLPPN) peptides based on the ARAM motif of Fc $\gamma$-RIIA were synthesized by Alta Bioscience Ltd (Birmingham, U.K.) and Zinsser Analytic Ltd (Maidenhead, U.K.) respectively. Pfu polymerase was from Stratagene (La Jolla, CA, U.S.A.). Linear$\mathrm{K}$ pre-adsorbent silica gel 150A TLC plates were from Whatman (Clifton, N.J., U.S.A.). Acti-gel was from Sterogene Bioseparations Inc. (St. Arcadia, CA, U.S.A.). All other reagents were of analytical grade or from previously described sources $[6,25]$.

\section{Preparation of human platelets}

Human blood was taken from drug-free volunteers on the day of the experiment. Platelet-rich plasma was obtained by centrifugation at $200 \mathrm{~g}$ for $20 \mathrm{~min}$ and platelets were isolated by centrifugation at $1000 \mathrm{~g}$ for $10 \mathrm{~min}$ in the presence of prostacyclin $(0.1 \mu \mathrm{g} / \mathrm{ml})$. Platelets were resuspended in $25 \mathrm{ml}$ of a modified
Tyrodes-Hepes buffer (134 mM NaCl/0.34 mM Na $\mathrm{NPO}_{4} /$ $2.9 \mathrm{mM} \mathrm{KCl} / 12 \mathrm{mM} \mathrm{NaHCO} / 20 \mathrm{mM}$ Hepes $/ 5 \mathrm{mM}$ glucose/ 1 $\mathrm{mM} \mathrm{MgCl}, \mathrm{pH} 7.3)$ in the presence of prostacyclin $(0.1 \mu \mathrm{g} / \mathrm{ml})$ and recentrifuged at $1000 \mathrm{~g}$ for $10 \mathrm{~min}$ before resuspension at a concentration of $2 \times 10^{9}$ cells $/ \mathrm{ml}$ in the above buffer containing $1 \mathrm{mM}$ EGTA and $10 \mu \mathrm{M}$ indomethacin. Platelets were left for $30 \mathrm{~min}$ at room temperature before experimentation. All experiments were carried out at $37^{\circ} \mathrm{C}$ in an aggregometer with continuous stirring ( $\left.800 \mathrm{rev} . \mathrm{min}^{-1}\right)$. Fc $\gamma$-RIIA was stimulated by cross-linking with $\mathrm{mAb}$ IV.3 $(1 \mu \mathrm{g} / \mathrm{ml})$ and $\mathrm{F}\left(\mathrm{ab}^{\prime}\right)_{2}$ antimouse IgG $(30 \mu \mathrm{g} / \mathrm{ml}) ; \mathrm{mAb}$ IV. 3 was added $60 \mathrm{~s}$ before $\mathrm{F}\left(\mathrm{ab}^{\prime}\right)_{2}$, the latter time being taken as the start of stimulation. Staurosporine and Ro 31-8220 were added $60 \mathrm{~s}$ before each agonist, while platelets were incubated with ST271 or BAPTA-AM for $10 \mathrm{~min}$ and $15 \mathrm{~min}$ respectively before agonist challenge.

\section{Immunoblotting studies}

Reactions were stopped by adding an equal volume of Laemmli buffer and samples were heated for $5 \mathrm{~min}$ at $95^{\circ} \mathrm{C}$. Proteins were separated by $10 \%$ SDS/PAGE and transferred to PVDF blotting membranes using a semi-dry transfer system (120 min, $15 \mathrm{~V})$. Membranes were incubated for $30 \mathrm{~min}$ at room temperature with $10 \%$ BSA in TBS-T (20 mM Tris/137 mM NaCl/0.1\% Tween$20, \mathrm{pH}$ 7.6) before probing for $60 \mathrm{~min}$ at room temperature with the primary antibody. Membranes were washed five times in TBS-T and bound primary antibody was detected by incubation for $60 \mathrm{~min}$ with HRP-conjugated sheep anti-(mouse IgG) or donkey anti-(rabbit IgG) as a secondary antibody. Membranes were washed in TBS-T and treated with ECL reagents before exposure to ECL-Hyperfilm. Blots were stripped of bound antibody by washing in TBS-T containing $2 \%$ SDS at $80^{\circ} \mathrm{C}$ for $40 \mathrm{~min}$. The membranes were washed three times with TBS-T and reprobed with secondary antibody to confirm removal of primary antibody. Membranes were then probed with a different primary antibody as required.

\section{Immunoprecipitation studies}

Platelets $\left(1 \times 10^{9}\right.$ cells $\left./ 500 \mu l\right)$ were lysed on ice for $30 \mathrm{~min}$ with an equal volume of ice-cold lysis buffer $(1 \% \mathrm{NP}-40 / 10 \mathrm{mM}$ EDTA/2 mM EGTA/2 mM $\mathrm{Na}_{3} \mathrm{VO}_{4} / 1 \mathrm{mM}$ PMSF $/ 300 \mathrm{mM}$ $\mathrm{NaCl} / 10 \mathrm{mM}$ Tris, $\mathrm{pH}$ 7.3). Insoluble cell debris was removed by centrifugation at $1300 \mathrm{~g}$ for $15 \mathrm{~min}$ and the supernatant precleared with $25 \mu$ l of protein A-Sepharose CL 4B which had been hydrated in TBS-T containing $10 \%$ BSA. Each sample was incubated with $1-5 \mu \mathrm{g}$ of rabbit anti-(syk antibody) for $90 \mathrm{~min}$ before addition of $25 \mathrm{ml}$ of protein A-Sepharose CL 4B. After a further incubation of $60 \mathrm{~min}$, the protein A-Sepharose CL 4B was precipitated by centrifugation at $11600 \mathrm{~g}$ for $30 \mathrm{~s}$ and washed five times in $1 \mathrm{ml}$ of TBS-T containing $1 \mathrm{mM}$ PMSF, $1 \mathrm{mM}$ $\mathrm{Na}_{3} \mathrm{VO}_{4}$ and $1 \mathrm{mM}$ EDTA. Immunoprecipitated proteins were subjected to SDS/PAGE, transferred to PVDF membrane and probed as described in the Immunoblotting studies section. For Fc $\gamma$-RIIA immunoprecipitation studies, solubilized samples were incubated with $1 \mu \mathrm{g}$ of $\mathrm{mAb}$ IV.3 without pre-clearing.

\section{Kinase assays in vitro}

After immunoprecipitation with anti-syk or mAb IV.3, precipitated proteins were resuspended in a kinase assay buffer (5 $\mathrm{mM} \mathrm{MgCl}_{2} / 5 \mathrm{mM} \mathrm{MnCl} / 100 \mathrm{mM} \mathrm{NaCl} / 20 \mathrm{mM}$ Hepes) and the reaction started by addition of $\left[\gamma^{32} \mathrm{P}\right] \mathrm{ATP}(250 \mu \mathrm{Ci} / \mathrm{ml})$; experiments were performed in a volume of $20 \mu \mathrm{l}$. After incubation for $15 \mathrm{~min}$ at room temperature, the reaction was terminated by addition of $0.5 \mathrm{ml}$ of ice-cold $100 \mathrm{mM}$ EDTA 
(pH 7.4). Samples were subjected to $10 \%$ SDS/PAGE and phosphorylated proteins visualized by autoradiography. In a limited number of studies, the identity of the phosphorylated amino acids was investigated. The appropriate region of the gel was incubated with $100 \mu \mathrm{l}$ of $6 \mathrm{M} \mathrm{HCl}$ at $110^{\circ} \mathrm{C}$ for $60 \mathrm{~min}$, and following centrifugation at $13000 \mathrm{~g}$, applied to Whatman silica gel 150A TLC plates. The TLC plates were developed in ethanol $/ 25 \%$ ammonia solution (35:16; v/v). Phosphoamino acids were visualized by autoradiography.

\section{Preparation of glutathione S-transferase (GST) fusion proteins encoding the SH2 domains of syk}

cDNA fragments encoding both $\mathrm{SH} 2$ domains of syk were amplified by $p F u$ polymerase using full-length human syk cDNA [25] as template and the following pair of primers: $5^{\prime}$ primer: 5' GCG GGATCC AGC GCC AAC CAC CTG CCC 3'; $3^{\prime}$ primer: 5' GCG GAATTC TCA GCC GAT TTT TTG ACA TGG 3'. A BamH1 site or an EcoRl site (underlined) was included in the $5^{\prime}$ and $3^{\prime}$ primers respectively for cloning. PCR products were precipitated and cut with the corresponding restriction endonuclease and ligated with the BamH1/EcoR1linearized prokaryotic expression vector pGEX-2T. Plasmids were then transformed into the Escherichia coli strain BL21 (DE3) for protein expression.

\section{Binding of proteins to the tandem SH2 domains of syk}

Platelet lysates were prepared using the lysis buffer described above. Insoluble cell debris was removed by centrifugation at $1300 \mathrm{~g}$ for $15 \mathrm{~min}$ and the supernatant pre-cleared with $10 \mu \mathrm{l}$ of glutathione-agarose. Each sample was incubated with $25 \mu \mathrm{g}$ of the GST fusion protein containing the tandem SH2 domains of syk on glutathione-agarose for $2.5 \mathrm{~h}$. The glutathione-agarose was precipitated by centrifugation at $11600 \mathrm{~g}$ for $15 \mathrm{~s}$ and twice washed in $1 \mathrm{ml}$ of lysis buffer and twice in $1 \mathrm{ml}$ of TBS-T containing $1 \mathrm{mM}$ PMSF, $1 \mathrm{mM} \mathrm{Na} \mathrm{VO}_{4}$ and $1 \mathrm{mM}$ EDTA. Precipitated proteins were subjected to $10 \%$ SDS/PAGE as described above.

\section{Binding of proteins to phosphorylated and non-phosphorylated peptides based on the ARAM motif of Fc $\gamma$-RIIA}

Peptides were dissolved at $2 \mathrm{mg} / \mathrm{ml}$ in $0.1 \mathrm{M}$ phosphate buffer, $\mathrm{pH} 7.0$, and coupled to Actigel, according to the instructions of the manufacturer, at room temperature for $2 \mathrm{~h}$. Platelets $\left(1 \times 10^{9} / \mathrm{ml}\right)$ were lysed at $4{ }^{\circ} \mathrm{C}$ in $1 \% \mathrm{NP}-40$ lysis buffer and centrifuged at $13000 \mathrm{~g}$ for $5 \mathrm{~min}$ to remove insoluble material. They were incubated with peptide-bound Actigel $(1 \%, v / v)$ for $2 \mathrm{~h}$ at $4{ }^{\circ} \mathrm{C}$. The Actigel was then washed by sequential resuspension in extraction buffer, high-salt buffer $(1 \mathrm{M} \mathrm{NaCl}$ in TBS-T) and twice with TBS-T. Samples were boiled in sample buffer for $10 \mathrm{~min}$ and proteins were separated by SDS/PAGE. Proteins were analysed by Western blotting (see above) or by biotinylation of PVDF membranes with ECL detection of streptavidin-HRP conjugation.

\section{RESULTS}

\section{Activation of platelets by FC $\gamma$-RIIA cross-linking and collagen is associated with tyrosine phosphorylation of 38 and $70 \mathrm{kDa}$ proteins}

We previously reported that cross-linking of Fc $\gamma$-RIIA induces tyrosine phosphorylation of 38 and $70 \mathrm{kDa}$ proteins in human platelets [5]. Phosphorylation of both proteins is also observed,

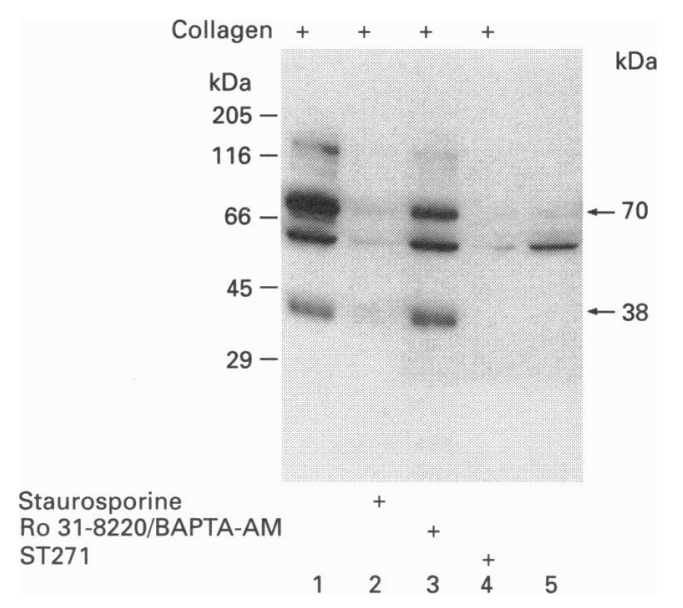

Figure 1 Anti-phosphotyrosine Immunoblots from collagen-stimulated platelets: effect of inhibitors

Platelets were stimulated with collagen $(100 \mu \mathrm{g} / \mathrm{ml})$ for $90 \mathrm{~s}$ and analysed for protein tyrosine phosphorylation with mAb $4 \mathrm{G10}$, as described in the Materials and methods section. Lane 1 collagen; lane 2, collagen and staurosporine $(10 \mu \mathrm{M})$; lane 3, collagen, BAPTA-AM $(40 \mu \mathrm{M})$ and Ro 31-8220 $(10 \mu \mathrm{M})$; lane 4, collagen and ST271 $(300 \mu \mathrm{M})$; lane 5, basal. Results are from one experiment representative of three others.

albeit slightly reduced, in the presence of a protein kinase $\mathrm{C}$ inhibitor, Ro 31-8220, and the intracellular calcium chelator, BAPTA-AM, suggesting that it is mediated, at least in part, independently of PLC [5]. These two proteins, together with Fc $\gamma$ RIIA itself [5], are among the first proteins to undergo tyrosine phosphorylation in platelets activated by cross-linking of $\mathrm{Fc} \gamma$ RIIA. The increase in tyrosine phosphorylation is inhibited completely in the presence of staurosporine or the tyrphostin tyrosine kinase inhibitor ST271 in parallel with inhibition of PLC activity [5]

The recent observation that collagen and Fc $\gamma$-RIIA induce tyrosine phosphorylation of PLC $\gamma 2$ [6] suggests that the two stimuli may activate platelets through a common pathway. Consistent with this, collagen also stimulates tyrosine phosphorylation of 38 and $70 \mathrm{kDa}$ proteins in the presence of Ro 31-8220 and BAPTA-AM, although phosphorylation of the $70 \mathrm{kDa}$ protein is slightly reduced under these conditions (Figure 1). Phosphorylation of the 38 and $70 \mathrm{kDa}$ proteins is inhibited completely in the presence of staurosporine or ST271 (Figure 1). The two tyrosine kinase inhibitors have previously been reported to inhibit collagen-induced activation of PLC in platelets $[27,28]$.

\section{Tyrosine phosphorylation of syk by Fc $\gamma$-RIIA cross-linking and collagen is independent of PLC}

One candidate for the $70 \mathrm{kDa}$ protein is the tyrosine kinase syk, which has recently been reported to undergo tyrosine phosphorylation in human platelets activated by cross-linking of Fc $\gamma$-RIIA [4] and in porcine platelets activated by collagen [24]. Immunoprecipitation studies using two different antibodies confirm that syk undergoes tyrosine phosphorylation in platelets activated by cross-linking of Fc $\gamma$-RIIA or by collagen (Figure 2). Phosphorylation of syk by collagen occurs with a lag phase of between 10 and $40 \mathrm{~s}$, depending on the donor, is concentrationdependent $(1-100 \mu \mathrm{g} / \mathrm{ml})$ and corresponds with the onset of protein tyrosine phosphorylation in whole cell lysates (Figure 2). Phosphorylation of syk by Fc $\gamma$-RIIA cross-linking also occurs with a similar delay and corresponds with the onset of protein 
(a)

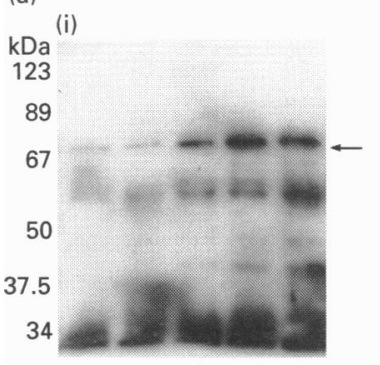

(b)

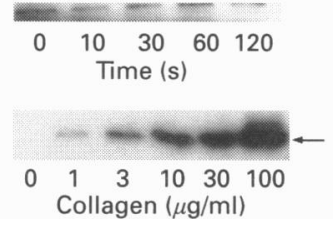

(ii)

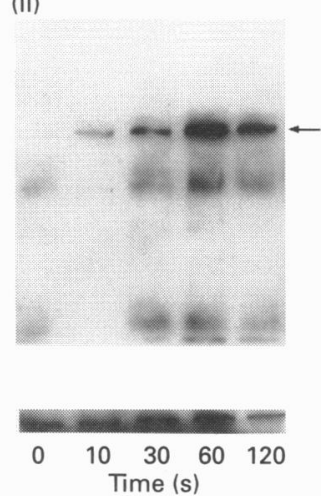

(a)

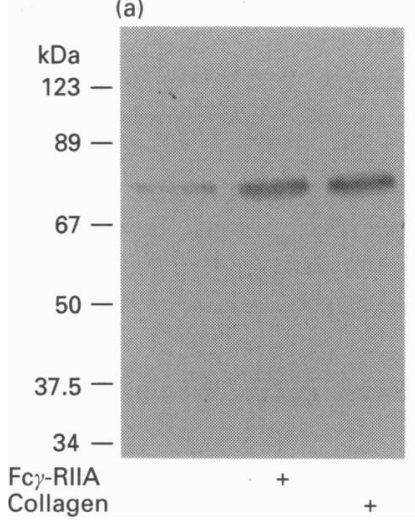

(b)

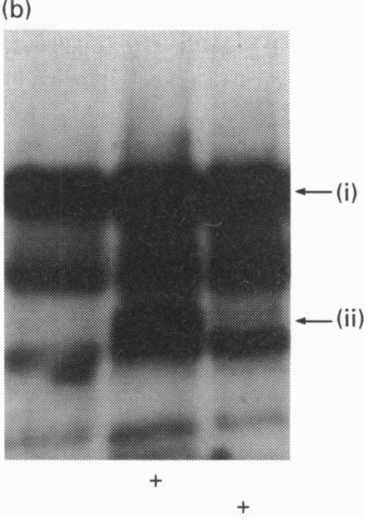

Figure 3 Kinase assays, in vitro, of syk immunoprecipitates from Fc $\gamma$-RIIAand collagen-stimulated platelets

Platelets were stimulated by cross-linking of Fc $\gamma$-RIIA with $1 \mu \mathrm{g} / \mathrm{ml}$ of mAb IV. 3 and $30 \mu \mathrm{g} / \mathrm{ml}$ of $F\left(a b^{\prime}\right)_{2}$ or $100 \mu \mathrm{g} / \mathrm{ml}$ of collagen for $60 \mathrm{~s}$, as described in the Materials and methods section. Syk was immunoprecipitated with an antibody raised against amino acids 257-35乞 within the linker region of syk as described in Figure 2. A kinase assay was performed in vitro on syk immunoprecipitates, as described in the Materials and methods section. Parts (a) and (b) illustrate short and long exposures respectively of the same experiment. Tyrosine phosphorylated proteins which co-migrate with syk and Fc $\gamma$-RIIA are indicated by (i) and (ii) respectively. The results are representative of three experiments. Similar results were obtained with a second antibody to syk raised against a peptide sequence within its kinase domain.
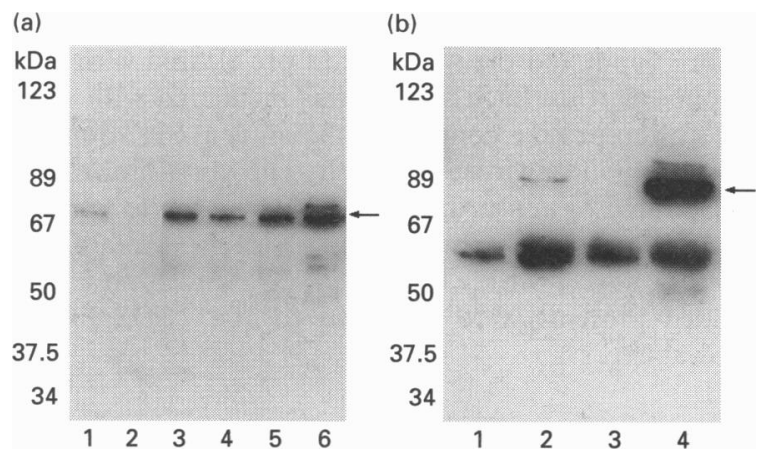

tyrosine phosphorylation in whole cell lysates (Figure 2). An uncharacterized tyrosine-phosphorylated protein at approx. $40 \mathrm{kDa}$ is also observed co-precipitating with syk in collagenactivated platelets (Figure 2). Several phosphorylated proteins have also been reported to associate with syk in mature Blymphocytes and related cell lines [29].

Phosphorylation of syk is associated with an increase in autophosphorylation activity in a kinase assay performed on syk immunoprecipitates (Figure 3a), which is consistent with previous reports that phosphorylation of syk is associated with an increase in its kinase activity [12]. The increase in autophosphorylation activity is not apparent in longer exposures of the autoradiogram because of loss of linearity in signal, but the additional phosphorylation of other proteins is observed (Figure $3 \mathrm{~b}$ ). Whilst the majority of these proteins are uncharacterized and are phosphorylated in both collagen- and Fc $\gamma$-RIIA-activated platelets, phosphorylation of a protein which co-migrates with Fc $\gamma$-RIIA is observed only in Fc $\gamma$-RIIA-activated cells (Figure $3 b)$. Although it is not clear from this experiment whether phosphorylation of Fc $\gamma$-RIIA is mediated by syk or by a coprecipitating kinase, Ghazizadeh et al. [10] have provided evidence that Fc $\gamma$-RIIA is a substrate for syk in THP-1 cells in vitro.

Phosphorylation of syk by Fc $\gamma$-RIIA and collagen is also observed in the combined presence of Ro 31-8220 and BAPTAAM (Figure 4), which is consistent with it being the same molecule as the $70 \mathrm{kDa}$ protein described above (see also Figure 1). Phosphorylation of syk under these conditions was reduced partially in Fc $\gamma$-RIIA-stimulated cells but potentiated in collagen-stimulated platelets (Figure 4), although the latter result

\section{Figure 4 Effect of Ro 31-8220 and BAPTA-AM on tyrosine phosphorylation of syk}

Platelets were pretreated with Ro $31-8220(10 \mu \mathrm{M})$ and BAPTA-AM $(10 \mu \mathrm{M})$ for 15 min before agonist stimulation. Syk was immunoprecipitated with an antibody raised against amino acids 257-352 within the linker region of syk, as described in Figure 2, and samples separated by $10 \%$ SDS/PAGE and immunoblotted for phosphotyrosine with mAb 4G10. The arrow shows the position of syk. (a) Platelets were stimulated in the absence (lanes 1,3 and 5) or presence (lanes 2, 4 and 6) of Ro 31-8220 and BAPTA-AM and stimulated by cross-linking of Fc $\gamma$-RIIA [ $1 \mu \mathrm{g} / \mathrm{ml}$ of IV.3 and $30 \mu \mathrm{g} / \mathrm{ml}$ of $\mathrm{F}\left(\mathrm{ab}^{\prime}\right)_{2}$ ] or $100 \mu \mathrm{g} / \mathrm{ml}$ of collagen for $60 \mathrm{~s}$ : lanes 1 and 2, basal; lanes 3 and 4, Fc $\gamma$-RIIA cross-linking; lanes 5 and 6, collagen. (b) Platelets were stimulated with thrombin (1 unit/ml) in the absence (lane 2) or presence (lane 3) of Ro 31 . 8220 and BAPTA-AM: lanes 1 and 4 are basal and Fc $\gamma$-RIIA-stimulated respectively. The results in (a) and (b) are representative of from four to six experiments, although potentiation of phosphorylation of syk by collagen in the presence of Ro 31-8220 and BAPTA-AM inhibitors was not consistently observed. Similar results were obtained with a second antibody to syk raised against a peptide sequence within its kinase domain.

was not seen in all experiments. The G-protein-coupled receptor agonist, thrombin, also induced phosphorylation of syk, albeit to a much lesser extent than that observed in collagen- and Fc $\gamma$ RIIA-activated platelets and, in contrast to above, this response 
(a)

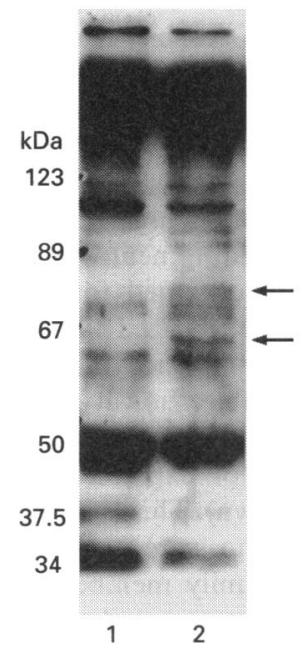

(b)

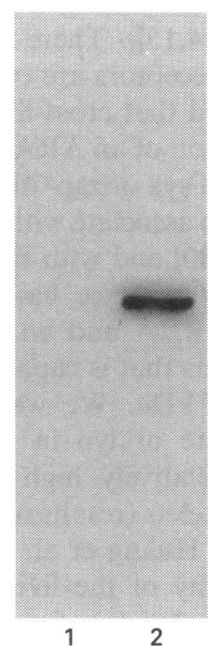

Figure 5 Binding of proteins to phosphorylated and non-phosphorylated peptides based on the ARAM motff of Fc $\gamma$-Rilla

(a) Protein binding. Platelet lysates from control cells were prepared as described in the Materials and methods section and incubated with non-phosphorylated (lane 1) and phosphorylated (lane 2) peptides based on the ARAM motif in Fc $\gamma$-RIIA that had been coupled to Acti-gel. Samples were analysed by $10 \%$ SDS/PAGE and stained for protein with biotin/streptavidin-conjugated HRP, as described in the Materials and methods section. The arrows indicate the selective concentration of two proteins. (b) Western blotting for syk. The gel in part (a) was immunoblotted for syk using an antibody raised against amino acids 257-352 within the linker region of syk. Results are representative of three experiments.

was inhibited completely by the combination of Ro 31-8220 and BAPTA-AM (Figure 4). These results demonstrate the existence of two distinct pathways of regulation of syk phosphorylation in platelets, distinguished by the requirement for PLC activity. They also provide further support for the hypothesis that collagen and Fc $\gamma$-RIIA cross-linking activate platelets through a common pathway.

The rapid onset of phosphorylation of syk by collagen and Fc $\gamma$-RIIA cross-linking suggests that syk may have an important role in mediating activation of PLC $\gamma 2$. Probing syk immunoprecipitates from collagen- and Fc $\gamma$-RIIA-activated platelets with antibodies to PLC $\gamma 2$, however, did not reveal the presence of the enzyme, suggesting that there is no direct association between the two proteins. Similarly, syk was not found in PLC $\gamma 2$ immunoprecipitates from platelets activated by cross-linking of Fc $\gamma$-RIIA, as measured by Western blotting or a kinase assay in vitro (results not shown).

\section{Syk associates with tyrosine-phosphorylated proteins in platelets activated by Fcy-RIIA cross-linking and by collagen}

The presence of an ARAM motif in the cytosolic portion of Fc $\gamma$ RIIA suggests that this may serve as a site of interaction with syk through its tandem $\mathrm{SH} 2$ domains. This possibility was tested using phosphorylated and non-phosphorylated peptides based on the Fc $\gamma$-RIIA ARAM motif. The peptides were coupled to Acti-gel and incubated with a platelet lysate from resting cells. Although a considerable number of proteins associate with both peptides, only two proteins of 67 and $70 \mathrm{kDa}$ are selectively concentrated by the phosphorylated peptide (Figure 5). The $70 \mathrm{kDa}$ protein was identified as syk by Western blotting (Figure 5), providing evidence for a direct association between the phosphorylated Fc $\gamma$-RIIA ARAM sequence and the two SH2

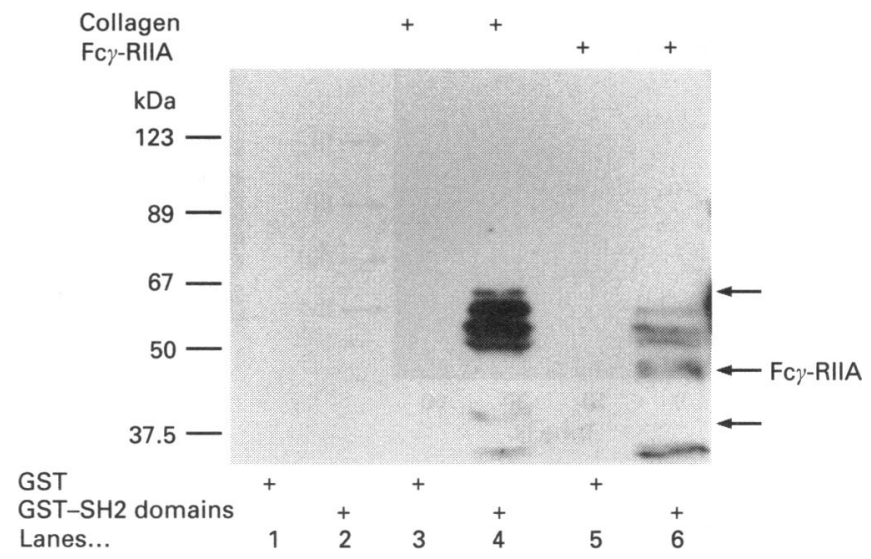

Figure 6 Binding of proteins to GST-syk tandem SH2 domains following cross-linking of $F(\gamma$-RillA or stimulation by collagen

Platelets were stimulated with collagen $(100 \mu \mathrm{g} / \mathrm{ml})$ or Fc $\gamma$-RIIA cross-linking [1 $\mu \mathrm{g} / \mathrm{ml}$ of IV.3 and $30 \mu \mathrm{g} / \mathrm{ml}$ of $\mathrm{F}\left(a b^{\prime}\right)_{2}$ ] for $60 \mathrm{~s}$, as described in the Materials and methods section. Samples were incubated with $25 \mu \mathrm{g}$ of GST-syk tandem SH2 fusion protein for $2.5 \mathrm{~h}$ at $4{ }^{\circ} \mathrm{C}$ Precipitated proteins were separated by $10 \%$ SDS/PAGE and immunoblotted for antiphosphotyrosine with 4G10. Lanes 1, 3 and 5, GST alone. Lanes 2, 4 and 6, GST-syk tandem SH2 fusion protein. Lanes 1 and 2, basal; lanes 3 and 4, collagen; lanes 5 and 6, Fc $\gamma$-RIIA cross-linking. The upper and lower arrows mark the positions of two uncharacterized tyrosinephosphorylated proteins in collagen-stimulated platelets; the middle arrow indicates the position of $F c \gamma$-RIIA. The results are representative of four experiments.

domains in syk. The identity of the $67 \mathrm{kDa}$ protein is not known.

A GST fusion protein containing the syk tandem SH2 domains was used to confirm that this region of syk interacts with Fc $\gamma$ RIIA. The fusion protein precipitated a number of tyrosinephosphorylated proteins from platelets activated by cross-linking of Fc $\gamma$-RIIA, including Fc $\gamma$-RIIA itself and three uncharacterized proteins with molecular masses in the region of 60-65 kDa (Figure 6). The latter three proteins are also present in collagen-stimulated cells, although Fc $\gamma$-RIIA is absent, together with two additional uncharacterized tyrosinephosphorylated proteins of 40 and $65 \mathrm{kDa}$ (indicated by the arrows in Figure 6). The $40 \mathrm{kDa}$ protein appears to be unrelated to the $38 \mathrm{kDa}$ protein described in the first section of the Results, as it is not found in GST-syk tandem SH2 immunoprecipitates from platelets activated by Fc $\gamma$-RIIA cross-linking; however, it may be related to a $40 \mathrm{kDa}$ protein present at low levels in syk immunoprecipitates from collagen-stimulated platelets that was observed in some but not all experiments (e.g. Figure 1). Drawing an analogy with the presence of tyrosine-phosphorylated Fc $\gamma$ RIIA in platelets activated by cross-linking of the receptor, the 40 and $65 \mathrm{kDa}$ proteins may be receptors for collagen (see Discussion section).

\section{An unidentified kinase and syk associate with Fo $\gamma$-RIIA}

A kinase assay carried out on Fc $\gamma$-RIIA immunoprecipitates reveals the presence of a constitutively associated kinase in nonstimulated cells that is capable of phosphorylating an uncharacterized protein of $67 \mathrm{kDa}$, which may be the kinase itself (Figure 7). The relationship of the phosphorylated protein to the $67 \mathrm{kDa}$ protein which associates with the tyrosinephosphorylated peptide based on the ARAM motif of Fc $\gamma$-RIIA (Figure 5) is not known. Several additional proteins undergo phosphorylation following activation of Fc $\gamma$-RIIA, including Fc $\gamma$-RIIA, a $70 \mathrm{kDa}$ protein which co-migrates with syk and an uncharacterized protein of $38 \mathrm{kDa}$ (Figure 7). The appearance of 


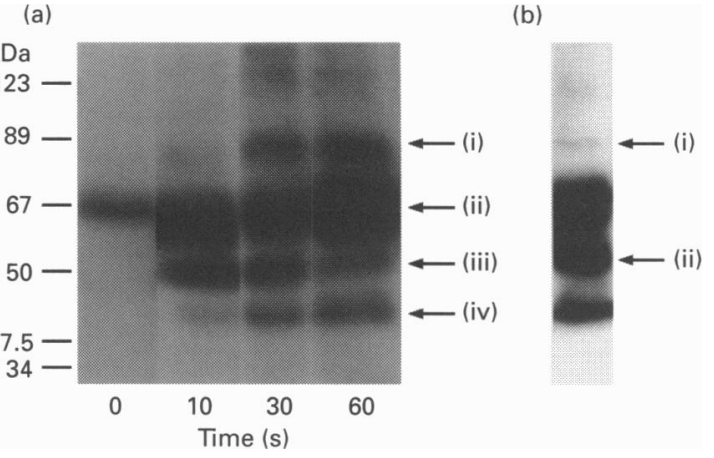

Figure 7 Association of proteins with Fc $y$-RIIA

Platelets were stimulated by $\mathrm{Fc} \gamma$-RIIA cross-linking [ $1 \mu \mathrm{g} / \mathrm{ml}$ of IV. 3 and $30 \mu \mathrm{g} / \mathrm{ml}$ of $\left.\mathrm{F}\left(\mathrm{ab}^{\prime}\right)_{2}\right]$ for $60 \mathrm{~s}$, as described in the Materials and methods section. (a) Kinase assay in vitro. After stimulation by Fc $\gamma$-RIIA cross-linking [1 $\mu \mathrm{g} / \mathrm{ml}$ of IV.3 and $30 \mu \mathrm{g} / \mathrm{ml}$ of $\left.\mathrm{F}\left(\mathrm{ab}^{\prime}\right)_{2}\right]$ for various times, Fc $\gamma$-RIIA was immunoprecipitated by mAb IV. 3 and a kinase assay performed in vitro, as described in the Materials and methods section. The arrows show the location of phosphorylated protein; (i) and (iii) comigrate with syk and $\mathrm{Fc} \gamma$-RIIA respectively; (ii) and (iv) show the positions of uncharacterized proteins of 67 and $38 \mathrm{kDa}$ respectively. The results are representative of three experiments. (b) Anti-phosphotyrosine Western blotting with mAb 4G10. Tyrosine-phosphorylated proteins which comigrate with syk and $\mathrm{Fc} \gamma$-RIIA [indicated by arrows (i) and (ii) respectively] were observed in platelets activated by cross-linking of $\mathrm{F} c \boldsymbol{\gamma}$-RIIA for $60 \mathrm{~s}$, but were absent in non-stimulated cells. The results in (a) and (b) are representative of three experiments.

these proteins in the Fc $\gamma$-RIIA immunoprecipitate occurs with a delay of 10-40 s, depending on the donor. Phospho-amino acid analysis demonstrated that phosphorylation of Fc $\gamma$-RIIA and the $38 \mathrm{kDa}$ protein occurs on tyrosine residues (not shown). Moreover, Fc $\gamma$-RIIA and the $70 \mathrm{kDa}$ protein become phosphorylated on tyrosine in activated cells (Figure 7b). Kiener et al. [9] and Chacko et al. [4] have also reported the presence of tyrosine-phosphorylated syk in Fc $\gamma$-RIIA immunoprecipitates from stimulated, but not resting, THP-1 monocytic cells and platelets respectively. These results demonstrate that Fc $\gamma$-RIIA is constitutively associated with an unidentified kinase and that cross-linking recruits additional tyrosine-phosphorylated proteins to the receptor complex, including syk and a $38 \mathrm{kDa}$ protein.

\section{DISCUSSION}

\section{Phosphorylation of syk in human platelets by collagen and Fc $\gamma$ - RIIA cross-linking}

The present study has demonstrated that syk is one of first proteins to undergo phosphorylation on tyrosine in platelets activated by collagen or Fc $\gamma$-RIIA cross-linking. Phosphorylation leads to an increase in the ability of syk to undergo autophosphorylation, providing evidence of kinase activation. Phosphorylation is also observed in the presence of a combination of Ro 31-8220 and BAPTA-AM, demonstrating that it is mediated, at least in part, independently of protein kinase $\mathrm{C}$ and elevation of $\left[\mathrm{Ca}^{2+}\right]_{1}$. The small reduction in phosphorylation of syk observed in some experiments in the presence of Ro 31-8220 and BAPTA-AM indicates a second mechanism of phosphorylation downstream of phospholipase $C$ (see later). These results suggest that syk may have an early and important role in mediating platelet activation by collagen and Fc $\gamma$-IIA receptors and can be added to the growing body of evidence that these two stimuli activate platelets through a common pathway.
The molecular basis of regulation of the syk/zap-70 family of tyrosine kinases by antigen receptors is beginning to emerge (for reviews see $[14,15])$. There is considerable evidence to suggest that antigen receptors are constitutively associated with an srclike kinase and that cross-linking induces activation, leading to phosphorylation of an ARAM sequence in the receptor complex and binding of syk or zap-70. Consistent with this, Fc $\gamma$-RIIA has been shown to associate with hck and lyn in activated monocytic THP-1 cells [30] and with fgr in resting neutrophils [31]. In the present study evidence has been obtained for an association between Fc $\gamma$-RIIA and an uncharacterized tyrosine kinase in resting platelets that is capable of phosphorylating an unknown protein of $67 \mathrm{kDa}$. We were unable, however, to detect the presence of src or lyn in the Fc $\gamma$-RIIA immunoprecipitates, despite the relatively high levels of expression of these two kinases in platelets (results not shown). This is in agreement with the results of Huang et al. [32] who were unable to detect the presence of any of the five src family members known to be present in platelets (i.e. fyn, hck, lyn, src and yes) in Fc $\gamma$-RIIA immunoprecipitates from resting and activated cells. These results may reflect a marked reduction in the interaction between srclike kinases and antigen receptors on extraction in NP-40 [33].

The ARAM sequence in Fc $\gamma$-RIIA is unique in having a spacer region of 12 amino acids between repeating YXXL motifs. Several lines of evidence have been presented in the present study to suggest that this phosphorylated motif is also able to interact with the $\mathrm{SH} 2$ domains of syk: (i) a tyrosinephosphorylated protein which comigrates with syk is present in Fc $\gamma$-RIIA immunoprecipitates from stimulated but not resting cells (similarly, Chacko et al. [4] also reported the presence of syk in Fc $\gamma$-RIIA immunoprecipitates); (ii) Fc $\gamma$-RIIA is present in syk immunoprecipitates from stimulated but not resting cells; (iii) phosphorylated Fc $\gamma$-RIIA interacts with a GST fusion protein containing the tandem $\mathrm{SH} 2$ domains of syk; and (iv) syk is selectively concentrated by a phosphorylated peptide based on the ARAM motif of Fc $\gamma$-RIIA. Taken together, these data provide strong evidence for an association between syk and the tyrosine-phosphorylated ARAM motif in stimulated but not resting platelets. The appearance of other phosphorylated proteins in the Fc $\gamma$-RIIA immunoprecipitate, including a protein of $38 \mathrm{kDa}$, demonstrate formation of a protein complex on cross-linking of Fc $\gamma$-RIIA, which may underlie platelet activation.

The receptor which underlies activation of platelets by collagen is not established; several surface proteins have been proposed to fulfill this role [34,35]. It is generally accepted that platelet adhesion to collagen is mediated through binding to the integrin $\alpha_{2} \beta_{1}$ [also known as glycoprotein (GP) Ia/IIa] [36] but several lines of evidence suggest that this protein does not mediate collagen-induced platelet activation. Analogues of collagen which do not bind to $\alpha_{2} \beta_{1}$ induce platelet activation [37], while the presence of antibodies to other cell-surface proteins is associated with inhibition of the response to collagen [34,35]. The list of candidate collagen receptors includes uncharacterized proteins of 62 and $65 \mathrm{kDa}[38,39]$, and GP VI which has a molecular mass of $62 \mathrm{kDa}[40,41]$. The similarity in the mechanism of platelet activation by collagen and Fc $\gamma$-RIIA cross-linking provides circumstantial evidence that collagen may regulate syk through an ARAM motif in its signalling receptor. It is therefore of interest that a GST fusion protein containing the tandem $\mathrm{SH} 2$ domains of syk binds to two uncharacterized tyrosinephosphorylated proteins of 40 and $65 \mathrm{kDa}$ which are absent in platelets activated by Fc $\gamma$-RIIA cross-linking. These two proteins represent potential signalling receptors for collagen and it is therefore of particular interest that one of these has a molecular 
mass close to that of the above proteins proposed as collagen receptors [38-41]. Similarly, in the rat basophilic leukaemic cell line, RBL-2H3, a fusion protein containing the tandem $\mathrm{SH} 2$ domains of syk was reported to bind to only three phosphotyrosine proteins, two of which were identified as the $\beta$ - and $\gamma$ chains of the Fc $\epsilon$ RI receptor, both of which contain an ARAM motif [42].

\section{Relationship between tyrosine phosphorylation of syk and PLC $\boldsymbol{y} 2$}

It has recently been reported that collagen, Fc $\gamma$-RIIA crosslinking and WGA induce platelet activation through tyrosine phosphorylation of PLC $\gamma 2[6,7]$, distinguishing this group of stimuli from those which induce activation through G-proteindependent pathways. Consistent with this, Blake et al. [6] reported that thrombin and the thromboxane mimetic U46619 do not induce significant tyrosine phosphorylation of PLC $\gamma 2$ in human platelets. The rapid phosphorylation of syk in platelets activated by collagen or Fc $\gamma$-RIIA cross-linking, independent of protein kinase $\mathrm{C}$ and elevation of $\left[\mathrm{Ca}^{2+}\right]_{\mathrm{i}}$, is consistent with a role of syk in the regulation of PLC $\gamma 2$ by these stimuli.

A role for syk in the regulation of PLC is supported by data obtained in some cells of the immune system. Aggregation of a chimeric receptor protein containing syk as its cytosolic tail is sufficient to initiate $\mathrm{Ca}^{2+}$ mobilization in a transfected $\mathrm{T}$ lymphocyte cell line, whereas aggregation of chimeric receptors with src family kinases does not elicit this response [43]. Activation of PLC and mobilization of $\mathrm{Ca}^{2+}$ is absent in response to receptor cross-linking in a syk-negative B-lymphocyte cell line, although lyn-negative cells exhibit normal formation of inositol 1,4,5-trisphosphate and a delayed increase in $\mathrm{Ca}^{2+}$ [44]. Tyrosine phosphorylation of syk in mast cells activated by cross-linking of the Fce-RI receptor is inhibited by the kinase inhibitor piceatannol in parallel with inhibition of receptor-stimulated formation of inositol 1,4,5-trisphosphate at concentrations which have little effect on the activation of lyn and receptor phosphorylation [45].

Syk is a cytosolic enzyme and must therefore translocate to the membrane for it to have a role in receptor signalling. One manner in which translocation can occur is through binding to Fc $\gamma$-RIIA following phosphorylation of its ARAM motif, and it has been speculated above that a similar interaction may occur in collagen-stimulated platelets. The apparent absence of an association between syk and PLC $\gamma 2$ in immunoprecipitates of the two enzymes, however, may reflect the presence of an additional protein involved in the regulation of PLC $\gamma 2$ phosphorylation. This may be another tyrosine kinase or an adaptor molecule that recruits PLC $\gamma 2$ to the membrane and thereby places it in the vicinity of syk. The adaptor molecule may undergo phosphorylation on tyrosine in order to enable interaction with PLC $\gamma 2$. Importantly, a $38 \mathrm{kDa}$ protein has been shown to form a complex with PLC $\gamma 1$ in T-cells following crosslinking of the T-cell receptor $[46,47]$, and a protein of similar molecular mass undergoes tyrosine phosphorylation in platelets activated by cross-linking of Fc $\gamma$-RIIA [5] and collagen (this study), independent of PLC. Alternatively, a possible association between syk and PLC $\gamma 2$ may have been below the level of detection, bearing in mind that syk and PLC $\gamma 1$ have been observed to associate in B-lymphocyte cells and related cell lines [29].

A wide variety of other agents also stimulate tyrosine phosphorylation of syk in porcine and human platelets (see the Introduction for a list of examples and references) and these can be divided according to their ability to regulate PLC: (i) stimuli which induce tyrosine phosphorylation of PLC $\gamma 2$, i.e. collagen,
WGA and Fc $\gamma$-RIIA; (ii) G-protein stimuli which induce activation of PLC but insignificant phosphorylation of PLC $\gamma 2$, i.e. thrombin and thromboxanes; and (iii) stimuli which do not induce activation of PLC, i.e. the $\mathrm{Ca}^{2+}$ ionophore A23187 and the fibrinogen receptor [48]. Phosphorylation of syk induced by the $\mathrm{Ca}^{2+}$ ionophore $\mathrm{A} 23187$ is independent of the release of thromboxanes and ADP and is inhibited by phorbol 12-myristate 13-acetate, suggesting that it is mediated by elevation of $\left[\mathrm{Ca}^{2+}\right]_{i}$ [21]. Thrombin may also induce phosphorylation of syk through elevation of $\left[\mathrm{Ca}^{2+}\right]_{\mathrm{i}}$, as its response is blocked in the presence of the combination of Ro 31-8220 and BAPTA-AM. The mechanism underlying phosphorylation of syk by the fibrinogen receptor is not known, although the receptor complex does not contain an ARAM motif and is not thought to have a role in the regulation of $\left[\mathrm{Ca}^{2+}\right]_{i}$. Thus, phosphorylation of syk appears to be mediated by at least three distinct pathways.

If syk is involved in the regulation of PLC $\gamma 2$ in platelets activated by collagen or Fc $\gamma$-RIIA cross-linking, then an explanation must be sought for the absence of significant phosphorylation of PLC $\gamma 2$ induced by G-protein receptor stimuli and the lack of stimulation of PLC by the $\mathrm{Ca}^{2+}$ ionophore A23187 or fibrinogen receptor activation. It is possible that syk is phosphorylated at distinct sites according to the stimulus used, that phosphorylation occurs at areas within the cell where syk is unable to gain access to PLC $\gamma 2$ or that phosphorylation of PLC $\gamma 2$ by syk is dependent on a phosphorylated intermediary protein whose role is to recruit PLC $\gamma 2$ to the membrane and which is only phosphorylated in platelets activated by collagen or Fc $\gamma$-RIIA cross-linking. Alternatively, the absence of significant phosphorylation of PLC $\gamma 2$ in thrombin-stimulated cells may reflect the low level of phosphorylation of syk induced by thrombin relative to that seen in collagen or Fc $\gamma$-RIIA-stimulated cells.

In conclusion, the present study has provided further evidence that collagen and Fc $\gamma$-RIIA cross-linking induce platelets through a common pathway that may involve tyrosine phosphorylation and activation of syk upstream of PLC $\gamma 2$. Further work is required to substantiate this hypothesis.

This work was supported by the Wellcome Trust and British Heart Foundation. S.P.W. is a Royal Society Research Fellow, A.P. is a Wellcome Veterinary Research Fellow and C.-C.L. holds a Special Fellowship from the Leukemia Society of America. We are grateful to Roche for the gift of Ro 31-8220 and to Anne Robinson and Jon Gibbins for stimulating discussion.

\section{REFERENCES}

1 Ferrell, J. E. and Martin, G. S. (1988) Mol. Cell. Biol. 8, 3603-3610

2 Golden, A. and Brugge, J. S. (1989) Proc. Natl. Acad. Sci. U.S.A. 86, 901-905

3 Nakamura, S. and Yamamura, H. (1989) J. Biol. Chem. 264, 7089-7091

4 Chacko, G. W., Duchemin, A., Coggeshall, K. M., Osborne, J. M., Brandt, J. T. and Anderson, C. L. (1994) J. Biol. Chem. 269, 32435-32440

5 Blake, R. A., Asselin, J., Walker, T. and Watson, S. P. (1994) FEBS Lett. 342, 15-18

6 Blake, R. A., Schieven, G. L. and Watson, S. P. (1994) FEBS Lett. 353, 212-216

7 Daniel, J. L., Dangelmaier, C. and Smith, J. B. (1994) Biochem. J. 302, 617-622

8 Poole, A. and Watson, S. P. (1995) Br. J. Pharmacol. 115, 101-106

9 Kiener, P. A., Rankin, B. M., Burkhardt, A. L. et al. (1993) J. Biol. Chem. 268, 24442-24448

10 Ghazizadeh, S., Bolen, J. B. and Fleit, H. B. (1995) Biochem. J. 305, 669-674

11 Agarwal, A., Salem, P. and Robbins, K. C. (1993) J. Biol. Chem. 268, 15900-15905

12 Taniguchi, T., Kobayashi, T., Kondo, J. et al. (1991) J. Biol. Chem. 266, 15790-15796

13 Reth, M. (1989) Nature (London) 338, 383-384

14 Weiss, A. and Littman, D. R. (1994) Cell 76, 263-274

15 Stuart, S. G., Simister, N. E., Clarkson, S. B., Kacinski, B. M., Shapiro, M. and Mellman, I. (1989) EMBO J. 8, 3657-3666

16 Ravetch, J. V. (1994) Cell 78, 553-560

17 Shiue, L., Green, J., Green, 0. M. et al. (1995) Mol. Cell. Biol. 15, 272-281

18 Gauen, L. K., Zhu, Y., Letourneur, F. et al. (1994) Mol. Cell. Biol. 14, 3729-3741 
19 Taniguchi, T., Kitagawa, H., Yasue, S. et al. (1993) J. Biol. Chem. 268, 2277-2279

20 Maeda, H., Taniguchi, T., Inazu, T., Yang, C., Nakagawara, G. and Yamamura, H. (1993) Biochem. Biophys. Res. Commun. 197, 62-67

21 Wang, X., Sada, K., Yanagi, S., Yang, C., Rezaul, K. and Yamamura, H. (1994) J. Biochem. 116, 858-862

22 Clark, E. A., Shattil, S. J., Ginsberg, M. H., Bolen, J. and Brugge, J. S. (1994) J. Biol. Chem. 269, 28859-28864

23 Ohta, S., Taniguchi, T., Asahi, M., Kato, Y., Nakagawara, G. and Yamamura, H. (1992) Biochem. Biophys. Res. Commun. 185, 1128-1132

24 Fujii, C., Yanagi, S., Sada, K., Nagai, K., Taniguchi, T. and Yamamura, H. (1994) Eur. J. Biochem. 226, 243-248

25 Law, C.-L., Sidorenko, S. P., Chandran, K. A. et al. (1994) J. Biol. Chem. 269, 12310-12319

26 Deans, J. P., Schieven, G. L., Shu, G. L. et al. (1993) J. Immunol. 151, 4494-4504

27 Blake, R. A., Walker, T. R. and Watson, S. P. (1993) Biochem J. 290, 471-475

28 Poole, A. W., Blake, R., Asselin, J. and Watson, S. P. (1993) Br. J. Pharmacol. 110, $41 \mathrm{P}$

29 Sidorenko, S. P., Law, C.-L., Chandran, K. A. and Clark, E. A. (1995) Proc. Natt. Acad. Sci. U.S.A. 92, 359-363

30 Ghazizadeh, S., Bolen, J. B. and Fleit, H. B. (1994) J. Biol. Chem. 269, 8878-8884

31 Hamada, F., Aoki, M., Akiyama, T. and Toyoshima, K. (1993) Proc. Natl. Acad. Sci. U.S.A. 90, $6305-6309$

32 Huang, M. M., Indik, Z., Brass, L. F., Hoxie, J. A., Schreiber, A. D. and Brugge, J. S (1992) J. Biol. Chem. 267, 5467-5473

Received 15 March 1995/24 May 1995; accepted 2 June 1995
33 Burg, D. L., Furtong, M. T., Harrison, M. L. and Geahlan, R. L. (1994) J. Biol. Chem. 269, 28136-28142

34 Santoro, S. A. (1988) in Platelet Membrane Receptors: Molecular Biology, Immunology, Biochemistry and Pathology (Jamieson, G. A., ed.), pp. 291-314, Liss, New York

35 Kehrel, B. (1995) Platelets 6, 11-16

36 Nieuwenhuis, H. K., Sakariassen, K. J., Houdijk, W. P. M., Nievelstein, P. F. E. M. and Sixma, J. J. (1986) Blood 68, 692-695

37 Morton, L. F., Hargreaves, P. G., Farndale, R. W., Young, R. D. and Barnes, M. J. (1995) Biochem. J. 306, 337-344

38 Chiang, T. M. and Kang, A. H. (1982) J. Biol. Chem. 257, 7581-7586

39 Ryu, R., Yoshida, A., Sugano, W. et al. (1992) Am. J. Haematol. 39, 25-31

40 Clemetson, K. J., McGregor, J. L., Dechavanne, M. and Lüscher, E. F. (1982) J. Clin. Invest. 70, 304-311

41 Moroi, M., Jung, S. M. and Shinmyozu, K. (1989) J. Clin. Invest. 84, 1440-1445

42 Kihara, H. and Siraganian, R. P. (1994) J. Biol. Chem. 269, 22427-22432

43 Kolanus, W., Romeo, C. and Seed, B. (1993) Cell 74, 171-183

44 Takata, M., Saba, H., Hata, A. et al. (1994) EMBO J. 13, 1341-1349

45 Oliver, J. M., Burg, D. L., Wilson, B. S., McLaughlin, J. L. and Geahlin, R. L. (1994) J. Biol. Chem. 269, 29697-29703

46 Gilliland, L. K., Schieven, G. L., Norris, N. A., Kanner, S. B., Aruffo, A. and Ledbetter, J. A. (1992) J. Biol. Chem. 267, 13610-13616

47 Sieh, M., Batzer, A., Schlessinger, J. and Weiss, A. (1994) Mol. Cell. Biol. 14, $4435-4442$

48 Watson, S. P., Poole, A. and Asselin, J. (1995) Mol. Pharmacol. 47, 823-830 